\title{
HIBAELEMZÉS ALKALMAZÁSA VESZÉLYES ÁRU SZÁLLÍTÁSÁRA
}

\section{APPLICATION OF THE FAILURE ANALYSIS IN THE HAZARDOUS TRANSPORTING}

\author{
Farkas Gabriella $^{1}$, Horváth Teréz Veronika ${ }^{2}$ \\ ${ }^{1}$ Óbudai Egyetem, Bánki Donát Gépész és Biztonságtechnikai Mérnöki Kar, Anyag- \\ és Gyártástudományi Intézet, Gyártástechnológiai Intézeti Tanszék, 1081-HU Buda- \\ pest, Népszínház u. 8.; Telefon: +36-16665339; farkas.gabriella@bgk.uni-obuda.hu \\ ${ }^{2}$ WestBridge Kft., 2030-HU Érd Fácán köz 10.; horvathterez86@gmail.com
}

\begin{abstract}
Quality assurance can be connected to the release of industrial development. It became important to the production of high-quality parts, scrap and thus reduce costs, increase customer satisfaction and profit. Different methods have been developed to achieve security beside the quality. The failure analysis first appeared in the field of military industry to ensure the prevention of the occurrence of errors. The FMEA process has been successfully applied in the automotive industry, communications, food safety, pharmaceuticals and the use of this technology in all aspects of pre-production products and services is available today. Transporting the bitumen is dangerous process for two reasons. On one hand the material, on the other hand the transport of substances (persons, means of transport, environmental protection, plant security) is dangerous processes. We present in this article the particular process and the results of the analysis in this dangerous transport process.
\end{abstract}

Keywords: failure analysis, FMEA, hazardous transporting

\section{Összefoglalás}

A minőségbiztosítás megjelenése összeköthető az ipari termelés fellendülésével. Fontossá vált a jó minőségű alkatrészek gyártása, a selejtszám és ezzel a költségek csökkentése, valamint a vevői megelégedettség és a profit növelése. Különböző módszereket, eljárásokat fejlesztettek ki, melyeknek célja a minőség mellett a biztonság. A hibaelemzés először a hadiipar területén jelent meg biztosítva a hibák előfordulásának megelőzését. Az FMEA eljárást sikeresen alkalmazza az autóipar, a híradástechnika, az élelmiszerbiztonság, a gyógyszeripar és napjainkra a termékelőállítás és a szolgáltatás szinte minden területén. A bitumen szállítása két szempontból is veszélyes folyamat, egyrészt önmagában az anyag, másrészt az anyag szállítása (személyekre, közlekedési eszközökre, környezetvédelemre, üzembiztonságra). A cikkben bemutatjuk ezt a különleges folyamatot és a veszélyes áruszállítás folyamatára elvégzett elemzés eredményeit.

Kulcsszavak: hibaelemzés, FMEA, veszélyes áruszállitás

\section{Veszélyes áru szállítása}

A szállítás valamilyen termék két földrajzi hely közötti továbbítása, ide értve a fel-, át- és lerakó helyeken történő manipulációs folyamatokat is. A szállítás egyidős az emberiséggel, a létfenntartáshoz elengedhetetlen volt a gyüjtögetés, vadászat 
majd az élelem közös helyre szállítása. Az árutermeléssel fejlődés vette kezdetét, úgy a szállítási útvonalak, mint a szállítási eszközök területén is. Kiépültek a városokat öszszekötő utak és a kereskedelem megjelenésével megindultak a szállitások, kezdetben kerék nélkül, majd kettő és több keréken. Az emberi erőt állatra majd gépekre cserélték. A XV. századtól gyors fejlődés indult a szállítás terén és elkezdtek olyan fedett jármüveket építeni, melyeket személy- és áruszállításra használtak. [1].

\subsection{Veszélyes áru}

A veszélyes árut szállítás szempontjából kétféleképpen tekinthetjük. Általánosságban azt nevezzük veszélyes árunak, amely az emberi életet, az anyagi javakat, a társadalmat és környezetet veszélyeztet. Szakmai nyelven valamely közlekedési ágazathoz kapcsolódó (közúti, vasúti, légi, belvízi, tengeri) jogszabályoknak megfelelő szállítása. A világ különböző pontjain többféle veszélyes árut állítanak elő. Amíg ezek a készítmények az előállítási helyükön tartozódnak, addig „csak” készítmények, attól kezdve, ha valamilyen irányba mozdítják, már veszélyes árunak minősülnek. Fontos, hogy ezeket a készítményeket elóállítási helyüktől függetlenül egységes jelölésekkel lássák el annak érdekében, hogy aki érintkezik vagy szállítja az adott veszélyes anyagot, tisztában legyen a készítmény tulajdonságaival. 2002-ben az ENSZ hatásköre alatt, létrehozták a Vegyi Anyagok Besorolásának és Címkézésének Globálisan Harmonizált Rendszerét (Globally Harmonized System of Classification and Labelling of Chemicals), röviden a GHS-t. Célja, egy olyan egységes rendszer kialakítása a világban, mely elóírja a veszélyes anyagok azonos besorolását. Segítve ezzel a nemzetközi kereskedelmet, a veszélyes anyagok előállításának, szállításának, felhasználásának nyomon követését. 2006-ban az Európai Unión belül megalakult a vegyi anyagok regisztrálásáról, értékeléséről, en- gedélyezéséről és korlátozásáról szóló 1907/2006 EK rendelet (Registration, Evaluation, Authorisation and Restriction of Chemicals), azaz a REACH azzal a céllal, hogy a vegyi anyagokkal kapcsolatos részletes információt szolgáltasson az anyagok életciklusának bármely pontján. Ez alapján készül a termékhez egy úgy nevezett Biztonsági adatlap, amely minden fontos információt tartalmaz azok számára, akik érintkezésbe kerülnek a veszélyes áruval. Ezt a dokumentumot a készítmény elöállítója készíti el. A szállítandó anyag tulajdonságaitól függően különböző veszélyességi osztályba sorolható, amelyet az ADR/RID tartalmaz [2].

\section{FMEA elemzés a veszélyes áru szállítási folyamatára}

FMEA (Failure Mode and Effects Analysis), hibamód és hibahatás elemzés egy szisztematikus módszer a termékek és folyamatok hibavizsgálatára. Az elemzés során a hangsúly a megelőzésen és azonosításon van, mielőtt a hiba bekövetkezne [3]. Az FMEA eljárás alkalmazása az autóiparban alapvető elvárás, a beszállítókkal szemben támasztott követelményeket tartalmazó szabvány (ISO/TS 16949) is tartalmazza [4]. Az elemzést szakértő csoport végzi, munkájuk során törekedni kell az eredmény objektivizálására. Ez nem mindig érhető el, mivel a döntés a szakértöi csoportokban résztvevő személyek közös tudásától függ [5].

A bitumen szállító nehéz félpótkocsik kialakítása specifikus. A bitumen az ADRben elöírt tartálykódú tartálytesttel szállítható. A félpótkocsik egykamrásak, a belsejükben hullámtörő lemezek gátolják az anyag hirtelen elmozdulását. Mivel a bitumen szállitáskor $170-200{ }^{\circ} \mathrm{C}$-os, ezért a rozsdamentes tartálytestet kívülről 10-15 $\mathrm{cm}$ vastag höszigetelö anyaggal borítják, amit egy vékony palást lemezzel fednek le. 
A szigetelés akadályozza meg az anyag dermedését.

Az hibaelemzés célja a meglévő bitumen szállitási folyamat gyengeségeinek feltárása, a kockázatok enyhítése, megteremtve ezzel egy biztonságosabb szállitási folyamatot. Ennek érdekében meg kell határozni a korrekciós és megelőző intézkedéseket, végül ellenőrizni kell ezek hatásait.

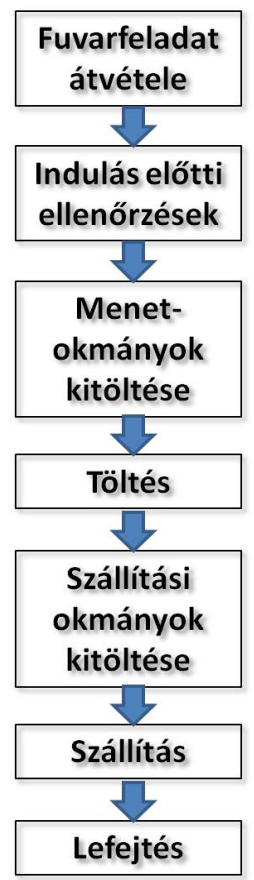

1. ábra. A bitumen szállitási folyamata az FMEA elemzésben

Az FMEA eljárás során a szakértő csapat feladata a folyamat (1. ábra) minden egyes lépésére meghatározni a lehetséges hibákat, elemezni a hibák előfordulásának kockázatát és értékelni a kockázati tényező (RPN) alapján. Az RPN értékét az alábbiak határozzák meg:

- A folyamatban jelentkező hatások súlyosságát, ezek fokozatait 1-10 között pont között értékeli. 10 pontot. A legsúlyosabb pontszámot kapja a folyamat azon része, mely hatását tekintve nem teljesíti a biztonsági vagy törvényi elöírásokat, és halálos vagy nagyon súlyos baleset áll fenn mind a gépjármüvezetőt mind a környezetét érintően. 1-es pontszámot akkor kaphat a következmény súlyossága, ha nincs észrevehető hatása a folyamatban.

- A hibaokok gyakorisága, 10 pontot ad a szakértő csapat, ha nagyon magas a hiba okának a gyakorisága, és 1 pontot, ha ritka a hiba okának az előfordulása.

- Ha a hibát lehetetlen észlelni az adott 10 pontot, ezzel szemben a hiba biztos ellenőrzésére 1 pontot kell adni.

\section{Eredmények}

Az elemzés célja a meglévő bitumen szállitási folyamat gyengeségeinek feltárása, a kockázatok enyhítése,

\begin{tabular}{|c|c|c|}
\hline KRIIIKUSLÁNCOLATOK & \multicolumn{2}{|c|}{ RPN Halmosott } \\
\hline 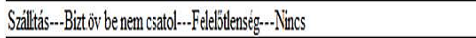 & 410,4 & $7 \%$ \\
\hline 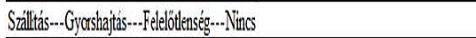 & 374,4 & $13 \%$ \\
\hline 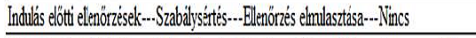 & 334,4 & $18 \%$ \\
\hline 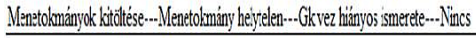 & $3) 4$ & $23 \%$ \\
\hline 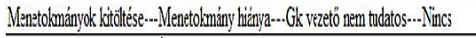 & 292,5 & $28 \%$ \\
\hline 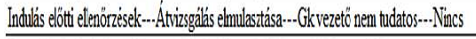 & 266,4 & $32 \%$ \\
\hline 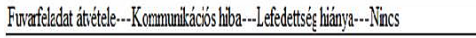 & 255,2 & $36 \%$ \\
\hline 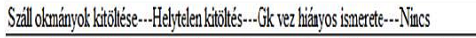 & 238 & $40 \%$ \\
\hline 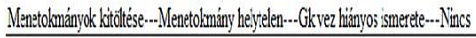 & 234 & $44 \%$ \\
\hline 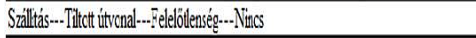 & 228 & $48 \%$ \\
\hline
\end{tabular}

2. ábra. A bitumen szállitási folyamata az FMEA elemzésben

A 2. ábra foglalja össze a hibamód és hatáselemzés kockázatértékelésének eredményeit. Jól látható, hogy 3 kritikus elemet szükséges vizsgálni. A szállítást, az indulás előtti ellenőrzéseket és a fuvarfeladat átvételét. Olyan javaslat kidolgozása van szükség, amellyel e kritikus elemek közül bármelyiket, vagy mindegyiket tudná csökkenteni kockázati szempontból, hiszen az említett kritikus elemek több kritikus láncolatban megjelennek. A legkritikusabb láncolatok mindegyike abból ered, hogy nincs hatékony ellenőrzése a folyamat elemeinek. 


\subsection{Javaslatok kidolgozása a kockáza- tok csökkentésére}

A szakértői csapat az összesítések alapján 3 javaslatot állított össze. Az első a kontroll csoport bővítésére, a második egy kamera beszerelésére a vontatóba, míg a harmadik a menet- és szállítási okmányok kitöltését érintő tipikus hibák kigyüjtésére vonatkozik. A kontroll csoport bővítése, megelőző oktatás tartása és vizsgáztatás csökkentené a kockázatok és hibák kialakulását, de ki nem zárja azokat. A gépjármüvezetőket folyamatos ellenőrizni kell, hogy visszacsatolást kapjon a vezetőség a minőségi, követelményeknek megfelelő munkavégzésükről. A kontroll csoport bővítése indokolt. Az új munkatárs feladatkörébe tartozna, a bitumen szegmensre vonatkozóan rendszeresen ellenőrizni például a gépjármüvezetők megjelenését, viselkedését a vevővel szemben; ellenőrzési lista (check lista) megfelelő kitöltését; okmányok meglétét. A vezetőfülkében elhelyezett kamera 5 percenként $0,5-1$ perc időtartamú felvételt készítene. A javaslat szerint a felvételt SD kártyán rögzítik. Így a kamerával regisztrálhatóak lennének a szabálytalanságok, például a biztonsági öv be nem csatolása, dohányzás, védőruha hiánya, pihenőidő be nem tartása, utas szállítás. A menetokmányok kitöltését jogszabály írja elő. A helytelen kitöltés büntetést von maga után és késedelmes teljesítést okozhat. A javaslat szerint a gépjármüvezetők rendszeres ismeretfelújító oktatása részesülnek és vizsgáznak, amellyel javítható a gépkocsivezetők hiányos ismerete, illetve a nem tudatos, figyelmetlen viselkedés.

A megvalósult intézkedés összhatását (3. ábra) tekintve a várt $1550 \mathrm{RPN}-$ nél nagyobb mértékü változást hozott, hiszen kisebb a megvalósult intézkedések RPN száma a fehér, tervezett mutatótól, mely bizonyítja milyen hatékony a javaslat megvalósítása.

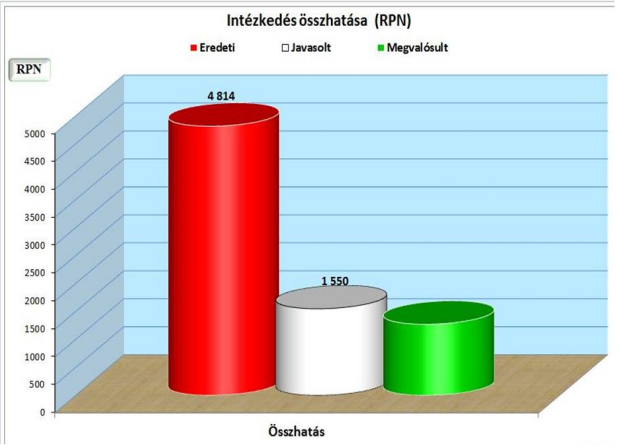

3. ábra. $A$ bitumen szállitási folyamata az FMEA elemzésben

\section{Következtetések}

Az FMEA eljárással feltártuk a bitumen szállításának folyamatában előforduló hibákat és hiba okokat. A kritikus elemek, hibák és láncolatok súlyozása során felismertük a folyamatban rejlő kockázatokat és javaslatainkkal sikerült e rizikófaktorok számait jelentősen csökkenteni. Biztonságosabbá téve a bitumenszállítási tevékenységünket, mérsékeltük a gépjármüvezetőkre, vevőinkre, társadalomra és környezetre gyakorolt hatásunk veszélyességi fokát.

\section{Szakirodalmi hivatkozások}

[1] Magyary István: Szállítmányozási ismeretek. Károly Róbert Főiskola Kézirat, Gyöngyös 2005. pp. 5-16.

[2] Gerhard M., Markus , Erdei Péter: Veszélyes áruk szállitása 2015-ös ADR alapján 1. kiadás MKFE. pp. 7-20.

[3] Robin E. McDermott, Raymond J. Mikulak, Michael R. Beauregard: The basics of FMEA (2nd Edition), CRC Press. 2008. pp. 11.

[4] D.H. Stamatis: Failure Mode and Effect Analysis (FMEA from Theory to Execution), 2nd Edition, ASQ. 2003. pp. 129.

[5] Szamosi Barna, Pokorádi László: $A z$ interszubjektiv tudás hatása az FMEA elemzésre. Repüléstudományi Közlemények, Szolnok, XXVII. évfolyam 2015/1. pp. 7380. 